\title{
IAMJ
}

INTERNATIONAL

AYURVEDIC

MEDICAL JOURNAL

ISSN: 23205091

Impact Factor: 5.344

\section{A PHARMCEUTICO ANALYTICAL STUDY OF AMAVATARI RASA - A HERBAL FORMULATION}

\author{
$\underline{\text { Anitha Somarajan }}^{1}$, Laxmi B Kurle ${ }^{2}$, Shankara Gowda ${ }^{3}$ \\ ${ }^{1}$ 3rd Year P.G Scholar, ${ }^{2}$ Associate Professor, ${ }^{3}$ Professor and HOD; \\ Dept of Rasashastra; Bhaishajya Kalpana, Taranath Govt. Ayurvedic Medical College, Bellari, Karnataka, India
}

Corresponding Author: dr.anitha.somarajan@gmail.com

https://doi.org/10.46607/iamj1308102020

(Published online: October 2020)

Open Access

(C) International Ayurvedic Medical Journal, India 2020

Article Received:18/09/2020 - Peer Reviewed:29/09/2020 - Accepted for Publication:03/10/2020

D) Check for updates

\begin{abstract}
Ayurveda is the most ancient medical sciences which deal with the powerful medicines with the use of herbals, minerals and herbo-minerals. Amavatari Rasa is one of the most powerful Ayurvedic formulation which comes under the polyherbal formulations, it contains Eranda moola, Triphala, Shuddha Chitraka, Shuddha Vatsanabha as main ingredients and Gomutra as Bhavana dravya indicated in SarvaVatavikara. as it is a VatsanabhayuktaKashtoushadi and irrespective of other Kashtoushadis its name and its less dose indicates that it is more potent than the other Amavataharakashtoushadhis, assimilation in the body is much faster even though the dose is very less and it can competent with other Amavatahara Rasaushadis. Amavatari Rasa was prepared as per the classical reference as there was no analytical standards available for Amavatari rasa in Ayurvedic pharmacopeia of India to check its quality, in this study an effort has been made to carry out the pharmaceutico Analytical study of Amavatari Rasa. The result obtained will be the reference standards and can also be used for future studies on Amavatari Rasa standardization.
\end{abstract}

Keywords: Amavatari Rasa, Pharmaceutico Analytical Study 


\section{INTRODUCTION}

Ayurveda is a monumental contribution of India to the world. As the name implies, Ayurveda (Ayuh: life, Veda: knowledge) is an organized body of knowledge of healthy living. Rasashastra and bhaishajyakalpana is an integral part of Ayurveda plays a crucial role and it is concerned with the preparation, uses, effects and mode of action of the drugs. Khalvi Rasayanas are the medicine prepared by specially designed grinding which acts as an elixir by preventing old age, prolonging life and cures the diseases. The specialty of Khalvi Rasayanas lies in binding different varieties of drugs into a single molecular form and here by minimizing the dose and more efficacious in their actions. The trituration process facilitates to fulfill the objectives. Amavatari Rasa comes under the KhalviRasayana Kalpana. Amavatari Rasa is a classical formulation, mentioned by different Acharyas in the management of Amavata There are 5 references of Amavatari Rasa found in different classical texts with different ingredients, Bhavana Dravyas, Matra, Anupana, and indications. Among these Amavatari Rasas the drug selected for study from Rasendra Chintamani which is purely herbal, unexplored and a unique preparation mentioned in Amavatadhikara and for Sarva Vata Vikaranut. But not found as a prescribed drug. The foremost reason for this is its non-availability in the markets. As it has not been the part of the classical preparations of most manufacturing companies. Amavatari Rasa contains Eranda moola, Triphala, Gomutra, Shuddhachitraka, Shuddhavatsanabha. as it is a Vatsanabhayuktakashtoushadi and irrespective of other kashtoushadis its name and its dose indicates that it is more potent than the other amavataharakashtoushadhis, assimilation in the body is much faster even though the dose is very less and it can competent with other Amavatahara Rasaushadis. In our classics amavata is considered as a yapya diseases because of the Pharmacological activities of each ingredients of it Amavatari Rasa it can act on the amavata from its early stages and the composition is like that it can be used for long term. It acts Deepana, Pachana, VataAnulomana, Jwaraghna, Soolahara, Shothagna, Swedajanana, Rasayana. The quality of each ingredient of Amavatari Rasa is very significant on the symptoms of Amavata, especially Vatsanabha and Eranda moola. In addition, its convenient form of administration and dosage (1 ratti) will be more acceptable and will increase its usage in preventing and curing in Amavata. Though the raw materials such as the Erandamoola, Triphala, Gomutra, Shuddhachitraka, Shuddhavatsanabha are available in abundance and cost effective, the formulation somehow has not been studied in depth for its potent Amavatahara properties. Importance of this study is to establish a purely herbal yoga on Amavata that is in fewer doses.

\section{Materials and Methods}

Pharmaceutical study involved in the preparation of Amavatari Rasa:

1. Vatsanabhashodhana by Gomutrasthapana for 3 days under sunlight3.

2. Chitrakashodhana by Churnodhakasthapana for 1 day4

3. preparation of fine powder of other Ingredients.

4. preparation of homogeneous mixture of Amavatari Rasa ingredients.

5. Gomutra bhavana is done for 7 days till it becomes completely dried fine powder5.

Table 1: Table showing the list of Ingredients with quantity

\begin{tabular}{|l|l|l|l|l|l|l|l|}
\hline SI no & Ingredients & Scientific name & Quantity (in parts) & SI no & Ingredients & Scientific name & Quantity(in parts) \\
\hline 1 & Eranda moola & Ricinus communis & $80 \mathrm{gms}$ & 1 & Eranda moola & Ricinus communis & $80 \mathrm{gms}$ \\
\hline 2 & Haritaki & Terminalia chebula & $80 \mathrm{gms}$ & 2 & Haritaki & Terminalia chebula & $80 \mathrm{gms}$ \\
\hline 3 & Vibhitaki & Terminalia bellirica & $80 \mathrm{gms}$ & 3 & Vibhitaki & Terminalia bellirica & $80 \mathrm{gms}$ \\
\hline
\end{tabular}




\section{Method of preparation:}

Procedure: Specified quantity Erandamoola was taken in a clean Khalva yantra. To this Haritaki, Vibhitaki, Amalaki were added one by one and triturated with each for 1 muhurthakaala for homogenous mixing. To this mixture Shudha Chitraka is added and triturated for 1 muhurthakaala. Then ShodhitaVatsanabha was added and triturated slowly for $1 \mathrm{mu}$ hurthakaala till the homogenous mixture of Amavatari Rasa is obtained. Then QS of Gomutra which was sufficient to immerse the powdered mixture of AVR was added and triturated well until the dry powder of AVR was obtained. The procedure was repeated for 7 days and it is stored in an airtight container.

\section{Observations}

- After adding Gomutra AVR colour dark Khaki changed to khaki colour.
- In the beginning for about 1 hour (after adding Gomutra) the Bhavana was easy due to liquid consistency of the contents of khalva.

- After 1 hour of Bhavana the liquid consistency changed to paste consistency and by this time the movement of peshaniwas not as easy as earlier. Gomutra smell was appreciated during Bhavana.

- After 3 hours of Bhavana almost all the Gomutra was absorbed and the AVR mixture turned to smooth paste and after $1 \mathrm{hr}$ it turned into a semisolid state with lumps and Bhavana became quite uneasy.

- After $61 / 2$ hours of Bhavana the AVR turned into fine powder with colour of light khaki and smooth consistency.

Table 2: Showing Classical Parameters for Analysis of AVR-BB

\begin{tabular}{|l|l|l|}
\hline Test & Observation AVR-BB & Observation AVR-AB \\
\hline Varna & Dark Khaki & Khaki \\
\hline Rasa & Tikta, Kashaya & Tikta, Kashaya, Lavana \\
\hline Sparsha & Mridu & Mridu \\
\hline Gandha & Characteristic & Characteristic \\
\hline
\end{tabular}

Table 3: Showing Results of Physical Tests of AVR-BB, AVR-AB,

\begin{tabular}{|l|l|l|}
\hline Parameters & AVR-BB & AVR-AB \\
\hline Loss on Drying at $105^{\circ} \mathrm{C}$ & $6.09 \%$ & $6.27 \%$ \\
\hline Total ash & $6.41 \%$ & $16.71 \%$ \\
\hline Acid insoluble ash & $0.79 \%$ & $1.41 \%$ \\
\hline Water soluble ash & $3.07 \%$ & $4.37 \%$ \\
\hline Alcohol soluble extractives & $18.09 \%$ & $13.87 \%$ \\
\hline Water soluble extractives & $18.38 \%$ & $35.21 \%$ \\
\hline pH $(10 \%$ aqueous solution) & $3.91+/-0.10$ & $4.81+/ 0.10$ \\
\hline
\end{tabular}

Table 4: Showing Results Chemical Tests of AVR

\begin{tabular}{|l|l|l|}
\hline Sample & Sodium & Potassium \\
\hline AVR-BB & $0.01 \%$ & $0.44 \%$ \\
\hline AVR-AB & $0.08 \%$ & $1.21 \%$ \\
\hline
\end{tabular}

- SEM-EDX: 
Table 5: Showing SEM-EDX Results of AVR-BB

\begin{tabular}{|l|l|l|}
\hline Element & Weight $\%$ & Atomic\% \\
\hline $\mathrm{C}$ & 60.66 & 67.92 \\
\hline $\mathrm{O}$ & 37.09 & 31.17 \\
\hline $\mathrm{Na}$ & 0.36 & 0.21 \\
\hline $\mathrm{Mg}$ & 0.04 & 0.02 \\
\hline $\mathrm{Cl}$ & 1.03 & 0.39 \\
\hline $\mathrm{K}$ & 0.27 & 0.09 \\
\hline $\mathrm{Ca}$ & 0.54 & 0.18 \\
\hline
\end{tabular}

Table 6: Showing SEM-EDX Results of AVR-AB

\begin{tabular}{|l|l|l|}
\hline Element & Weight $\%$ & Atomic\% \\
\hline $\mathrm{C}$ & 63 & 73.04 \\
\hline $\mathrm{O}$ & 26.21 & 22.81 \\
\hline $\mathrm{Na}$ & 0.86 & 0.52 \\
\hline $\mathrm{Mg}$ & 0.02 & 0.01 \\
\hline $\mathrm{Cl}$ & 4.1 & 1.61 \\
\hline $\mathrm{K}$ & 3.89 & 1.38 \\
\hline $\mathrm{Ca}$ & 1.54 & 0.53 \\
\hline $\mathrm{Zn}$ & 0.39 & 0.08 \\
\hline
\end{tabular}

FTIR: XRD

Table 7: Showing Particle Size of AVR-BB, AVR-AB EFFECTIVE DIAMETER

\begin{tabular}{|l|l|l|}
\hline Sample & Z-Average (d.nm) & Pdl \\
\hline AVR-BB & 938.9 & 0.759 \\
\hline AVR-AB & 728.9 & 0.693 \\
\hline
\end{tabular}

Table 8: Showing results of Thin Layer Chromatography of AVR-BB, AVR-AB Under Visible Light

\begin{tabular}{|l|l|l|}
\hline Rf & AVR-BB & AVR-AB \\
\hline 0.05 & Green & Green \\
\hline 0.10 & --- & Light orange \\
\hline 0.13 & --- & --- \\
\hline 0.23 & --- & --- \\
\hline 0.31 & --- & Pale orange \\
\hline 0.34 & --- & --- \\
\hline 0.44 & --- & --- \\
\hline 0.62 & --- & --- \\
\hline 0.72 & --- & --- \\
\hline 0.82 & -- & --- \\
\hline 0.85 & Orange & Pale orange \\
\hline 0.87 & --- & --- \\
\hline & & \\
\hline
\end{tabular}


Table 9: Showing results of Thin Layer Chromatography of AVR-BB, AVR-AB,

\begin{tabular}{|l|l|l|}
\hline Under Long UV & \multicolumn{2}{l|}{} \\
\hline $\mathrm{Rf}$ & AVR-BB & AVR-AB \\
\hline 0.05 & Fluorescent green & Fluorescent green \\
\hline 0.1 & Fluorescent green & Bright fluorescent green \\
\hline 0.13 & --- & --- \\
\hline 0.23 & --- & --- \\
\hline 0.31 & --- & Light fluorescent green \\
\hline 0.34 & --- & Fluorescent green \\
\hline 0.44 & --- & --- \\
\hline 0.62 & --- & --- \\
\hline 0.72 & --- & --- \\
\hline 0.82 & -- & --- \\
\hline 0.85 & Bright fluorescent green & Bright fluorescent green \\
\hline & & \\
\hline
\end{tabular}

\section{DISCUSSION}

Gomutra is a well-established Bio-Enhancer of animal origin. It increases the Bioavailability of Antimicrobial, Antifungal, and Anticancer Agents. Bioavailability is the best way to Reduce Dose, Toxicity, and Cost of Drug. Therefore, use of Gomutra with the core Drug is the best way to achieve this target \& the UshnaTeeksha properties will increase the Potency of the Formulation. When we discuss about $\mathrm{pH}$ is the negative logarithm of the hydrogen. The $\mathrm{pH}$ of AVR - BB is 3.91, AVR - $\mathrm{AB}$ is $4.81 \cdot$ Both the AVR products were found to be Acidic in nature which indicates that they can be easily absorbed in the stomach by Passive Diffusion. Acidic pH is may be due to presence of Katu and Teekshna Guna Pradhana Dravya in this Formulation. The total ash value of AVR - BB is 6 $.41 \%$, AVR - AB is $16.71 \%$ which indicate that in the present study poly herbal preparation contains more amounts of Inorganic Constituents and more amounts of Organic and Bio Human available particles. Hence it can be said that the prepared AVR is within the Standard of Physical Analysis of Herbal Drugs. Acid insoluble ash value of AVR BB is $79 \%$ and $A V R$ AB IS1.41\%. It indicates that in AVR-BB, AVR -AB 99.21\% \& 98.59\% of Drug Constituents are Acid Soluble, More the Acid insoluble ash, less the drug absorption in Acid media of stomach the slight increase in the Acid insoluble ash value in AVR -AB is due to the 7 Bhavana with Gomutra. Water soluble ash of AVR-BB is $3.07 \%$, AVR - $\mathrm{AB}$ is $4.37 \%$, it indicates that in AVR-AB slight increase in water soluble ash than before Bhavana these values denote that water is not a soluble media for it. The salivary secretions, gastric enzymes play an important role in the efficacy of AVR the Anupana Dravya Ghrita plays an important role in the efficacy of AVR. Water soluble extractives and Alcohol soluble extractive value, Water soluble extractives of AVR - BB are $18.38 \%$ and Alcohol soluble extractive is $18.09 \%$. Water soluble extractives of AVR - AB are $35.21 \%$ and Alcohol soluble extractive is $13.87 \%$. Both in AVR percentage of alcohol soluble extract is less than that of water-soluble extracts, which clearly indicates presence of more amounts of water-soluble contents both preparations \& the water is the best suitable media for this Formulations to exhibit its Pharmacological Actions.

When we come across with the discussion on loss on drying at $105^{\circ} \mathrm{C}$, it is a physical test to detect the percentage of least moisture content and hence the shelf life of the sample. The least loss on drying at $105^{\circ} \mathrm{C}$ the better will be the drug. In the present study AVR$\mathrm{BB}, \mathrm{AVR}-\mathrm{AB}$, possessed $6.09 \%, 6.27 \%$ loss on drying at $105^{\circ} \mathrm{C}$.Because of the organic material processing there was $0.18 \%$ hike in the loss on drying in AVR - AB when compared to that of AVR-BB is due to the Bhavana DravyaGomutra.

Discussion on Particle Size by ZETAPALS:

Particle size is one of the factors which will affect dissolution and absorption of drugs. Particle size and surface area are inversely proportional to each other, as 
particle size decreases surface area increases. This leads to increase in Dissolution Drug and Rapid Absorption is a measure of the rate of solution. Mean Particle size of AVR - BB is 938.9, AVR -AB is 728.9 The Particle Size of the final products of AVR is reduced due to the Bhavana Samskara so as reduction in particle size will lead to better Absorption and Bioavailability of the Drug

\section{Discussion on Elemental Analysis:}

It is a physical test to detect the percentage Sodium \& Potassium values: Percentage of Sodium in AVR-BB is $0.01 \%$; AVR-AB is $0.08 \%$., Percentage of Potassium in AVR-BB is $0.44 \%$, AVR-AB is $1.21 \%$., The increase in Sodium and Potassium values seen in AVR-AB is due to the 7 days Bhavana with Gomutra.

\section{Discussion on SEM-EDX:}

SEM-EDX study reveals the accurate elemental analysis of the sample, this study of elements enables us to explore Major, Minor and Trace elements. SEM-EDX study reveals Major, Minor \& Trace elements. The percentage of elements present in AVR-BB is C$60.66 \%$, O-37.09\%, Na- $0.36 \%$, Mg- $0.04 \%$, Cl- $1.03 \%$, $\mathrm{K}-0.27 \%$, Ca- 0.54 . The percentage of elements present in AVR-AB are C- 63\%, O- 26.21\%, Na- 0.86\%, Mg- $0.02 \%$, Cl- $4.1 \%$, K- $3.89 \%$, Ca- $1.54 \%$, Zn$0.39 \%$. The percentage of Carbon has been increased in AVR-AB compared to AVR-AB it may be due to the addition of organic material. The reduction in $\mathrm{Ox}$ ygen percentage gradually in AVR-AB compared to AVR-BB may be due to the Oxidation Process. In Amavatari Rasa the other minor elements like K, Ca, $\mathrm{Na}, \mathrm{Cl}$, and $\mathrm{Mg}$ may be due to the Bhavana of AVR with Gomutra. The percentage of $\mathrm{Cl}, \mathrm{K}$, Ca have been increased in AVR-AB compared to AVR-BB it may be due to the 7 Bhavanas with Gomutra as mentioned earlier Gomutra is Mineral Rich containing many Elements. Variation in the percentage of elemental composition also occurred due to heterogeneity of the sample, a factor that cannot be ruled out. The above change in the percentage of elements may be due to the heat treatment, which causes breaking of bonds and the formation of new bonds resulting in the increase and decrease of other elements. The obtained peaks of AVR-BB, AVR-AB were compared with the standard peaks. It showed the presence of different functional groups like Amine, $\alpha, \beta$-unsaturated ketone, Amide, Alkene, Aromatics, Acid, Alcohol, Alkane, Carbonyl, Alkyl halide, Ester, and Ether. This shows the presence of organic compounds in the drug. Under visible light in AVR- BB 2 bands were observed at Rf values $0.05,0.85$ and colour of the bands Green, Orange respectively. In AVR- AB 4 bands were observed at $\mathrm{Rf}$ values $0.05,0.10,0.31,0.85$ and colour of the bands Green, Light orange, Pale orange, Pale orange respectively. Under Long UV in AVR- BB 3 bands were observed at $R f$ values $0.05,0.10,0.85$ and colour of the bands fluorescent green, fluorescent green, Bright fluorescent green respectively. In AVR$\mathrm{AB} 5$ bands were observed at $\mathrm{Rf}$ values $0.05,0.10$, $0.31,0.34,0.85$ and colour of the bands fluorescent green, Bright fluorescent green, Light fluorescent green, fluorescent green, Bright fluorescent green respectively.

Under visible light 2 extra bands were observed in AVR after Bhavana\& in Under Long UV 2 extra bands were observed in AVR after Bhavana which indicates that the phytoconstituents are added after Bhavana. In present study TLC of the drug mixture is compared with the final product. The final product shows the presence of various herbal ingredients present in the formulation and hence shows that the preparation is not adulterated.

\section{REFERENCES}

1. Acharya Dhundhuk Nath. Rasendrachintamani. With "Siddhiprada"- Hindi translation. By Prof. Siddhi Nandan Mishra, First edition, Varanasi-1, Chaukhambaorientalia; 2000. 9th chapter, Amavatadhikara, verse 3, 255pp.

2. Sri Madhavakara. Madhava Nidanam with the Sasnskrit commentary Madhukosa by Vijayarakshita \& amp; Srikantha Datta Edited with Vimala-Madhudhara Hindi commentary \& amp; Notes by Dr. Brahmananda Tripati. Varanasi: Chaukhamba Surbharati Prakashan; volume1 25th chapter, verse $6570-577 \mathrm{pp}$.

3. Sri Sharma Sadananda. Rasa Tarangini. Edited by Pandit Kashinath Shastri.11th Edition. Varanasi: Motilal Banarasidas Publication; 1979. 24th Taranga, Verse $575,753 \mathrm{pp}$. 
4. Anonymous. The Ayurvedic formulatory of India. 2nd Edition. New Delhi: The Controller of publications civil line; 2003. Part-1, Shodana Prakarana 40,369pp.

5. Kaviraj Govind Das Sen. Bhaishajya Ratnavali Edited with 'Sidhiprada' Hindi commentary by Prof. Siddhi Nandan Mishra, Varanasi: Chaukhamba Surbharati Prakashan; 2009. 4th Chapter, verse 61, 74pp.

\section{Source of Support: Nil}

\section{Conflict of Interest: None Declared}

How to cite this URL: Anitha Somarajan et al: A Pharmceutico Analytical Study of Amavatari Rasa - A Herbal Formulations. International Ayurvedic Medical Journal \{online\} 2020 \{cited October, 2020\} Available from: http://www.iamj.in/posts/images/upload/4649 4655.pdf 